\title{
CONTINUITY, COORDINATION AND COOPERATION AS MEDIATORS BETWEEN ECONOMIC AND NON-ECONOMIC SATISFACTION - A SALES PERSPECTIVE
}

\author{
Nils M. HØGEVOLD ${ }^{1}$, Göran SVENSSON ${ }^{2}$, \\ Pierre MOSTERT ${ }^{3^{*}}$, Mariëtte L. ZIETSMAN ${ }^{4}$ \\ 1, 2 Department of Marketing, Economics and Innovation, \\ Kristiania University College, Oslo, Norway \\ ${ }^{3,4}$ Department of Marketing Management, University of Pretoria, Pretoria, South Africa
}

Received 28 November 2019; accepted 05 June 2020

\begin{abstract}
There is a gap in literature as to how multidimensional satisfaction fits into a nomological network with continuity, coordination and cooperation. Furthermore, most studies focusing on these constructs are limited to a buyer perspective. The objective of this study is to fill this gap by testing a model whereby continuity, coordination and cooperation are regarded as mediators between economic and non-economic satisfaction specifically within business-sales representative relationships, thereby establishing a foundation to assess the structural properties between economic satisfaction and non-economic satisfaction within a business sales context. Managerial implications offered in the paper were discussed and the practical relevance and implementation thereof validated by experienced sales directors. This study contributes by revealing that continuity, coordination and cooperation to some extent mediates separately as well as cumulatively the relationship between economic satisfaction and non-economic satisfaction within a business sales context. Subsequently, it contributes by extending our understanding in relation to existing theory and previous studies of business relationships to a business sales perspective.
\end{abstract}

Keywords: economic satisfaction, non-economic satisfaction, continuity, coordination, cooperation, business sales relationships.

JEL Classification: M31, M21, C3.

\section{Introduction}

Successful long-lasting relationships established and maintained between sales representatives and customers are critical for organizations' success, growth, and ultimately survival (Mangus \& Ruvio, 2019). Central to establishing business relationships is customer satisfaction (Grewal \& Sharma, 1991) due to the belief that it leads to a number of positive behaviors

${ }^{\star}$ Corresponding author. E-mail: pierre.mostert@up.ac.za 
(Oliver et al., 1997), including repurchase intentions, spreading positive word-of-mouth, behavioral and attitudinal loyalty and customer retention (Grewal \& Sharma, 1991; Mbango \& Mmatli, 2019). In fact, satisfaction is of such importance in business relationships (Mungra \& Yadav, 2020) that it has been postulated that without ensuring customer satisfaction it would be impossible to develop and maintain quality relationships (Hyun, 2010).

When studying satisfaction, Geyskens, Steenkamp, and Kumar (1999) were some of the first researchers to advocate that it is not a unidimensional construct but rather comprises two separate dimensions, namely economic and non-economic satisfaction. The importance of distinguishing between economic and non-economic satisfaction lies therein that each has a distinct focus (Ulaga \& Eggert, 2006), holds varying relationships with various antecedents and outcomes (Geyskens et al., 1999) and failure to differentiate between them will diminish organizations' ability to successfully manage customer relationships (Geyskens \& Steenkamp, 2000). Researchers have thus increasingly adopted both economic and non-economic satisfaction as separate constructs when studying business relationships (Glavee-Geo, 2019; Høgevold et al., 2019; Payan et al., 2019).

Due to their direct interaction with customers, sales representatives' behavior is particularly important since it has a significant influence on customers' satisfaction (Grewal \& Sharma, 1991) and ultimately building long-term relationships with customers (Friend et al., 2018; Lussier \& Hall, 2018; Rodriguez et al., 2018). In fact, since sales representatives play a critical role in ensuring economic and non-economic satisfaction, and ultimately building strong relationships with customers, it is not surprising that organizations are increasingly using satisfaction measures when evaluating the effectiveness of salesforces (Jap, 2001). This stands to reason when considering that due to continuous economic satisfaction, over time trust is built and with it a greater willingness to form relationships (Del Bosque Rodriguez et al., 2006; Ferro et al., 2016). This view is supported by Rutherford (2012) who found a relationship between economic and noneconomic satisfaction in buyer-sales representative interactions, by specifically noting that economic satisfaction with the sales representative has a strong influence on noneconomic satisfaction. Rutherford (2012, p. 965) furthermore concluded that "..., when buyers are economically satisfied in the relationship, they will be more committed to the relationship with the salesperson". This is an important point since it is critical within a competitive environment that sales representatives understand how to appropriately build relationships (Rutherford, 2012).

Ensuring satisfaction within business relationships is simply not sufficient because organizations who are serious about developing long-term relationships have to move to an approach that is truly based on cooperation (Wilson \& Nielson, 2001). In fact, it is sales representatives' cooperative intentions and cooperation with customers to find the best possible solutions for customers' needs that establishes quality relationships (Huntley, 2006) and accordingly forms the foundation for continuing the relationship in the future (Holm et al., 1996).

The interrelationship between satisfaction, cooperation, coordination and continuity becomes clear when considering that the collaboration between relational parties will result in cost reductions, improved logistics and overall performance improvements, ultimately result- 
ing in improved profitability (Nyaga et al., 2010). This view is supported by Anderson and Narus (1990) who explain that cooperation within a business relationship to attain mutual objectives and benefits results in perceptions of compatibility within the relationship, which in turn, together with achieving sought after outcomes, result in a "strong chemistry" and satisfaction with the relationship. Of greater importance from a relational point of view is that overall performance improvements due to relational exchanges and collaboration results in greater satisfaction with the overall relationship, economic satisfaction and relationship continuity (Nyaga et al., 2010). Continuity, in turn, is important as it is indicative of the sustainability of the relationship (Kumar et al., 1995).

Although previous studies researched the constructs used in this study (or a combination thereof with other constructs), the interrelationship included in the proposed nomological network in this study has not been empirically tested. For example, the study by Ferro et al. (2016) tested a model where trust and commitment were mediators between economic and non-economic satisfaction. In the study by Padín, Ferro, and Svensson (2017), continuity, coordination and cooperation were positioned as outcomes of satisfaction, where satisfaction was measured as a unidimensional construct instead of a twodimensional construct (i.e. economic and non-economic satisfaction). Whereas the study by Payan et al. (2019) included economic and non-economic satisfaction, it did not consider continuity. Furthermore, their study proposed economic satisfaction as an outcome of coordination, and furthermore did not find a direct relationship between economic and non-economic satisfaction. There is thus still a gap in literature on how multidimensional satisfaction fits into a nomological network with continuity, coordination and cooperation. It is important to keep in mind that the abovementioned studies were conducted within a buyer setting and not within a business sales context. This could be problematic since, as highlighted by Rutherford (2012), one should cautiously interpret and applying findings from a buyer context to a sales context.

The research objective of this study is accordingly to fill this gap by testing a model whereby continuity, coordination and cooperation are regarded as mediators between economic and non-economic satisfaction specifically within business sales relationships. The aim is to establish a foundation to assess the structural properties between economic satisfaction and non-economic satisfaction in a business sales context.

The rest of the article contains the following main sections: theoretical framework; research model and hypotheses; methodology; results; discussion and managerial implications; and finally, conclusions.

\section{Theoretical framework}

This study positions economic satisfaction as an antecedent to non-economic satisfaction, and furthermore positions non-economic satisfaction as a postcedent to economic satisfaction. While previous studies researched the influence of other intermediary constructs as mediators between economic and non-economic satisfaction, including trust and commitment (Ferro et al., 2016; Mpinganjira et al., 2017), this study specifically studies three alternative constructs, namely cooperation, coordination and continuity (Padín et al., 2017). 


\subsection{Satisfaction}

Satisfaction, viewed from the disconfirmation of expectations paradigm, refers to an emotional response to the judgmental difference between some normative standard (i.e. expectations) and performance outcome (Ulaga \& Eggert, 2006). Within a business context, satisfaction embodies the overall evaluation, attitude and feeling about an exchange relationship, with the evaluation process incorporating both economic and social aspects of the relationship encounter (Sanzo et al., 2003).

It is important to acknowledge that, within a business context, the post-purchase evaluation of a specific purchase transaction offers very little insight concerning future repurchasing behavior, customer loyalty and forming long-term relationships. To evaluate the effect of satisfaction on loyalty and behavioral intentions, it is accordingly necessary to study the cumulative effect of a set of distinct encounters aggregated over time - thus cumulative or overall satisfaction (Fehr \& Rocha, 2018; Jones \& Suh, 2000). Cumulative satisfaction is also a better indicator of customers' overall attitude since customers may, due to situational and other factors, have a low transaction-specific satisfaction, but still experience overall satisfaction with the organization (Jones \& Suh, 2000). Cumulative satisfaction is thus, not surprisingly, regarded an essential indicator of an organization's overall current and future performance due to its link to customers' attitudes, future intentions and preserving customer-organization relationships (Garbarino \& Johnson, 1999).

Researchers have realized that customer satisfaction within business relationships is not a unidimensional construct but comprises two dimensions, namely economic satisfaction and non-economic satisfaction (Glavee-Geo, 2019; Høgevold et al., 2019; Mpinganjira et al., 2017). A two-dimensional approach to studying customer satisfaction is important since failure to differentiate between them will diminish organizations' ability to effectively manage its customer relationships (Geyskens \& Steenkamp, 2000). Thus, similar to previous studies within a business relationship contexts (eg. Farrelly \& Quester, 2005; Ferro et al., 2016; Payan et al., 2019; Rutherford, 2012), this study considered economic and non-economic satisfaction as separate constructs.

\section{Economic satisfaction}

Economic satisfaction refers to the positive affective reaction to economic rewards that emerge from relationships (Fehr \& Rocha, 2018; Geyskens \& Steenkamp, 2000). Economic satisfaction can accordingly be operationalized as customers' positive evaluation of only the economic outcomes emerging from business relationships, including goals and rewards such as discounts, sales volume, margins, growth and market opportunities (Farrelly \& Quester, 2005; Geyskens \& Steenkamp, 2000). Economically satisfied customers will therefore view relationships as successful based on financial outcomes, achievement of goals and effectiveness and efficiency of the partnership (Ting, 2011). It is thus not surprising that conflict is likely to occur in exchange relationships due to dissatisfaction with economic-related issues (Geyskens et al., 1999). Economic satisfaction is accordingly especially important in the beginning of business relationships (Ferro et al., 2016) due to the fact that, initially, parties focus on economic results and benefits that will ensure their survival and growth (Del Bosque Rodriguez et al., 2006; Geyskens \& Steenkamp, 2000). 


\section{Non-Economic satisfaction}

Non-economic satisfaction, also labelled social satisfaction, refers to the positive evaluation of psychosocial aspects emerging from business relationships (Fehr \& Rocha, 2018; Geyskens \& Steenkamp, 2000). Non-economic satisfaction accordingly centers on the evaluation of interactions between the parties and therefore reflects the social context in which the relationship develops (Del Bosque Rodriguez et al., 2006; Sanzo et al., 2003). Non-economic satisfaction results from involvement and clear communication between the parties, mutual respectfulness and integrity of the exchange partner (Ferro et al., 2016; Lee et al., 2008). Attainment of non-economic satisfaction is important in business relationships since the parties find interactions uncomplicated, rewarding and enjoyable, and therefore prefer working together and exchanging ideas (Geyskens et al., 1999).

\subsection{Continuity}

Continuity can be defined as exchange parties' intentions to stay in a relationship; it is thus a reflection of the likelihood of continuing collaborations between them (Kumar et al., 1995). It is important not to mistake continuity with loyalty. While expectations of continuity shows relational parties' behavioral intentions to preserve the relationship, this may be due to apathy, unwillingness to seek for alternatives due to time or other constraints, or high switching costs (Palmatier, 2008). Continuity in terms of behavioral intentions may, accordingly, not be reflective of true loyalty (Palmatier, 2008). From this overview it is clear that various degrees of continuity can be distinguished, where relational parties can be categorized on a continuum according to their continuity expectations (Noordewier et al., 1990). One the one side of this continuum (discrete transaction), relationship parties are more transactional focused, thereby suggesting a low likelihood of future interactions and collaboration, whereas at the other end (relational transaction), there is high probability of future interaction (Noordewier et al., 1990). Relationally-governed exchanges between parties are thus important for continuity intentions and long-term, mutually beneficial relationships, since the enforcement of obligations and delivering on expectations and promises occur through social processes that inspire relationship behavior norms which, in turn, could influence other aspects that are important to relationship development and maintenance, such as relationship quality (Harmon \& Griffiths, 2008).

\subsection{Coordination}

Coordination can be defined as the added information processing accomplished when multiple, connected parties, pursue objectives that a single party pursuing the same objective would not achieve (Malone, 1988). Thus, the reason why business parties coordinate efforts is to maximize profitability for both parties (Pei et al., 2020). For coordination to exist requires three distinct conditions: there has to be two or more parties; all parties must have responsibilities to perform certain tasks; and the purpose of the combined effort is to achieve a mutual purpose (Malone, 1988). In this study, coordination is conceptualized as the shared tasks, responsibilities and processes assumed by parties 
in an exchange relationship, with the explicit purpose to accomplish mutual objectives (Fehr \& Rocha, 2018; Ju \& Ha, 2019; Kang et al., 2018). Coordination can thus be viewed as the manifestation of collaborative actions between relational parties (Payan \& Svensson, 2007). In fact, if there is no interdependence between exchange parties, there is no reason to coordinate activities (Malone \& Crowston, 1994). Coordination is essential within business relationships as its absence may result in poor relationship outcomes in terms of sales, market share and growth and, ultimately, profits (Ju \& Ha, 2019; Kang et al., 2018; Medlin et al., 2005).

\subsection{Cooperation}

Cooperation, derived from the Latin word cooperari, which means to work together, to unite or to combine (Latdict, 2018; Morgan \& Hunt, 1994), is believed to be a key construct within business relationships (Payan et al., 2010; Woo \& Ennew, 2004). Cooperation can accordingly be viewed as those complementary actions by exchange parties to achieve reciprocal value and favorable outcomes (Anderson \& Narus, 1990), grounded in trust built over a period of time as relational parties grow in confidence in each other's motives in the relationship (Hagen \& Choe, 1998). Cooperation is thus, in essence, more attitudinal in nature as it reflects the willingness of relational parties to work together (Payan \& Svensson, 2007). In fact it is the inclination to collaborate to achieve mutual value - and thus the cooperation between exchange parties - that forms the foundation for the development of close business relationships (Huntley, 2006). It is thus not surprising that cooperation increases when sales people have a customer-focused orientation (Lussier \& Hall, 2018).

\section{Research model and hypotheses}

The research model (see Figure 1) proposes that positive economic satisfaction of a business sales relationship is key to continue and coordinate the relationship, thereby resulting in greater cooperation, which, in turn, influences non-economic satisfaction. Finally, positive economic satisfaction contributes to non-economic satisfaction in a business-sales representative relationship.

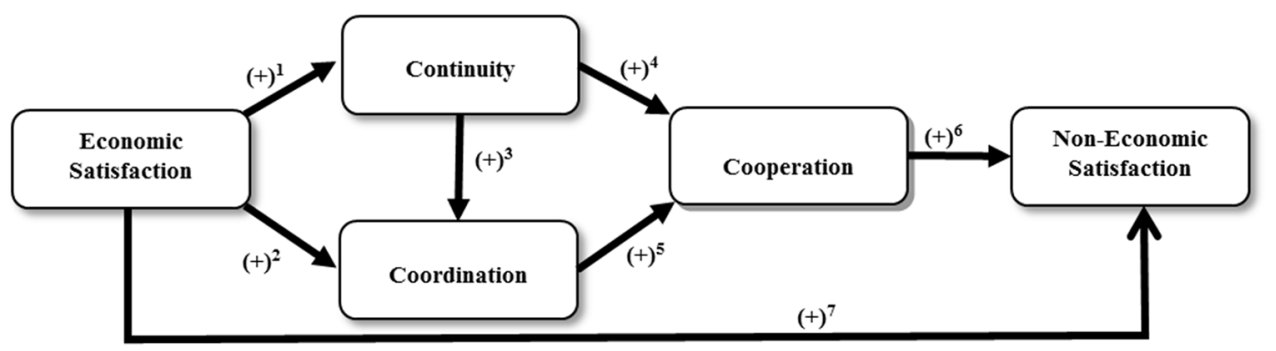

Figure 1. Research model and hypothesized relationships 


\subsection{Economic satisfaction and continuity}

Economic satisfaction is important in business relationships because of the economic results and benefits parties hope to get from transactions (Del Bosque Rodriquez et al., 2006; Ferro et al., 2016; Geyskens \& Steenkamp, 2000). It has furthermore been established that attaining customer satisfaction is a critical determinant of customer loyalty (Goncalves \& Sampaio, 2012) and for forming long-term relationships between exchange parties (Mpinganjira et al., 2013). On the other hand, Jiang, Shiu, Henneberg, and Naude (2016) concluded that relationship continuity should be considered an essential element for long-term relationships.

Nyaga et al. (2010) argue that relational parties who trust each other will be more satisfied and will, accordingly, endeavor to ensure the continuity of the relationship. This view has been supported by research establishing a positive relationship between satisfaction and continuity (Del Bosque Rodriquez et al., 2006; Mpinganjira et al., 2013; Padín et al., 2017; Ulaga \& Eggert, 2006), with Palmatier et al. (2006) furthermore establishing satisfaction as an antecedent of continuity and Glavee-Geo (2019) and Lee et al. (2008) proposing that economic satisfaction results in increasing relationship continuity. It can accordingly be hypothesized that:

$\mathrm{H}_{1}$ - Economic satisfaction relates positively to the expectancy to continue business-sales representative relationships.

\subsection{Economic satisfaction and coordination}

In their extensive literature review, Sarmah, Acharya, and Goyal (2006) found that relational parties implement several strategies to coordinate their business activities in an effort to ensure enhanced response times, timely supply, as well as improved customer service and key elements of economic satisfaction. This makes sense from a relational perspective when considering Malone and Crowston's (1994) findings that without interdependence between exchange parties, there is no reason to coordinate activities. This view is supported by Sahadev's (2008) explanation that the combination of exchange parties' economic satisfaction and coordination will lead to more relationship-building activities which, in turn, cultivates commitment.

The link between economic satisfaction and coordination becomes even more evident when one considers that these two constructs are regarded as the action alignment components of collaboration (Payan et al., 2019). As seen earlier, the absence of coordination in business relationships could possibly lead to poor relationship outcomes in terms of sales, market share and growth and profits (Kang et al., 2018; Medlin et al., 2005), thereby failing to offer economic satisfaction in terms of financial rewards stemming from the relationship (Geyskens et al., 1999).

Previous research has not only established that economic satisfaction contributes to important relational outcomes, such as coordination (Høgevold et al., 2019; Mpinganjira et al., 2013), but furthermore found a direct positive relationship between economic satisfaction and coordination (Padín et al., 2017; Payan et al., 2019; Payan \& Svensson, 2007). It can accordingly be hypothesized that: 
$\mathrm{H}_{2}$ - Economic satisfaction relates positively to coordination in business-sales representative relationships.

\subsection{Continuity and coordination}

Coordination between relationship parties entails the undertaking to jointly follow common compatible objectives and activities directed at establishing and maintaining the relationship (Payan \& Svensson, 2007; Woo \& Ennew, 2004). Thus, the coordination of activities between relational parties create interdependence between them (Holm et al., 1996). Coordination is of such importance that it is believed that coordination within firms results in better relationship quality and performance to external customers (Bradford et al., 2019). It is therefore not unexpected that Dabholkar, Johnston, and Cathey (1994) consider cooperative behavior as a critical element for successful long-term business relationships. Wilson and Nielson (2001) liken coordination within business relationships to a marriage, where the relational parties may experience pleasure and a sense of fulfilment from working and sharing together. It is thus reasonable to expect a relationship between continuity and coordination (Wilson \& Nielson, 2001).

It has been argued that a direct relationship should exist between continuity and cooperation since continuing positive exchanges between relational parties should, over time, lead to the parties increasingly becoming involved in a cooperative relationship (Wilson \& Nielson, 2001). This view is supported by research establishing a positive relationship between continuity and coordination (Sosa-Varela et al., 2011; Svensson \& Mysen, 2011; Svensson et al., 2013). It can thus be hypothesized that:

$\mathrm{H}_{3}$ - The expectancy to continue relates positively to coordination in business-sales representative relationships.

\subsection{Continuity and cooperation}

From the earlier discussion it became clear that cooperation is an important construct within business relationships due to exchange parties' willingness to work together to achieve reciprocal value and favorable outcomes (Anderson \& Narus, 1990; Huntley, 2006). It is thus not surprising when Payan et al. (2010) claim that it is difficult to conceive that a relationship can even exist or continue in the future without cooperation between the relational parties. The importance of cooperation in business relationships, and its interrelationship with continuity and coordination, becomes clear when considering that, if relational parties have a reciprocal understanding of how to coordinate exchange activities, they will be more likely to invest in the relationship and to broaden cooperation by including more undertakings in the relationship (Holm et al., 1996). Thus, increasing cooperation by also considering additional activities in the relationship will require further investing in the relationship, thereby resulting in a stronger commitment (and thus continuity of the relationship) by the parties (Holm et al., 1996).

Research findings support this reasoning by establishing that the expectation of continuity motivates relational parties to invest in the relationship, thereby resulting in greater cooperation (Poppo \& Zenger, 2002). Wilson and Nielson (2001) also found a relationship 
between continuity and cooperation, albeit indirectly through trust. Furthermore, recent studies found a positive relationship between continuity and cooperation (Sosa-Varela et al., 2011; Svensson \& Mysen, 2011; Svensson et al., 2013).

$\mathrm{H}_{4}$ - The expectancy to continue relates positively to cooperation in business-sales representative relationships.

\subsection{Coordination and cooperation}

Although coordination and cooperation are often used interchangeably by researchers within a business relationship context (Glas et al., 2019), the constructs are conceptually different and thus needs clarification (Naudé \& Buttle, 2000). Whereas coordination consists of explicit collaborative activities between relational parties, cooperation signals their willingness to work together to achieve mutual goals and is thus more attitudinal and goal oriented than coordination (Payan \& Svensson, 2007). Despite being conceptually different, the constructs are closely related, as is evident from the following perspective offered by Woo and Ennew (2004, p. 1257): “.., cooperative behavior includes the coordination tasks which are undertaken jointly and singly to pursue common and/or compatible goals and activities undertaken to develop and maintain the relationship". It is thus not unexpected that a number of studies found a positive relationship between coordination and cooperation (Høgevold et al., 2019; Payan et al., 2019; Sosa-Varela et al., 2011; Svensson et al., 2013). It can accordingly be hypothesized that:

$\mathrm{H}_{5}$ - Coordination relates positively to cooperation in business-sales representative relationships.

\subsection{Cooperation and non-economic satisfaction}

Through cooperation, relational parties will improve their overall performance and gain satisfaction and other benefits from the relationship (Wilson \& Nielson, 2001). This view is supported by Payan et al. (2019) who found that cooperation will enhance non-economic satisfaction, thereby contributing to the success of the relationship in the future.

Although a number of studies established positive relationships between cooperation and satisfaction (Chu et al., 2019; Payan et al., 2010), it should be noted that these authors viewed satisfaction holistically, thereby rather a non-economic satisfaction measure (Payan et al., 2019). Research, however, also found a positive direct relationship between cooperation and non-economic satisfaction specifically (Høgevold et al., 2019; Svensson et al., 2010). It can accordingly be hypothesized that:

$\mathrm{H}_{6}$ - Cooperation relates positively to non-economic satisfaction in business-sales representative relationships.

\subsection{Economic and non-economic satisfaction}

As discussed earlier, researchers determined that satisfaction is not a unidimensional construct, but comprises two distinct dimensions, namely economic satisfaction and non-economic satisfaction. Although it was established that economic and non-economic satisfaction 
are related (Del Bosque Rodriguez et al., 2006), it is difficult at times to predict the relationship between them given the cyclical nature of relationships (Farrelly \& Quester, 2005). Despite this, however, Ferro et al. (2016) and Mpinganjira et al. (2017) stress that attaining economic satisfaction at the onset of the relationship should set the foundation for a positive environment to build trust and commitment, two essential antecedents for social (noneconomic) satisfaction, and ultimately, loyalty. It is therefore not surprising that research established a positive relationship between economic and non-economic satisfaction (Ferro et al., 2016; Glavee-Geo, 2019; Høgevold et al., 2019; Mpinganjira et al., 2017; Rutherford, 2012). It can accordingly be hypothesized that:

$\mathrm{H}_{7}$ - Economic satisfaction relates positively to non-economic satisfaction in businesssales representative relationships.

\section{Methodology}

\subsection{Research context and sample}

The study population comprised multi-industrial Norwegian companies, identified via the Norwegian database of Sales Navigator on LinkedIn. The criteria used to select key informants were marketing or sales managers or directors or key account managers in order to research business-sales representative relationships. After identifying and contacting 841 key informants by phone, the researchers talked to 582 of them to determine whether they met the criteria to participate and to identify another sales representative at the same company should they not qualify.

The 523 sales representatives who met the criteria to participate in the survey had to complete our online questionnaire hosted on Qualtrics. Of the 310 responses returned (59.3\%), 98 were excluded due to incompleteness, resulting in a final sample of 214 (valid response rate of $40.9 \%$ ).

Respondents had to identify one significant customer they interacted with over the preceding year, and to think of this customer when completing the questionnaire. We ensured confidentiality by respondents not identifying the selected customer. Finally, key informants were asked to answer the questionnaire to their best ability to deliver quality responses.

Informant competency was checked (Campbell, 1955) by asking them how experienced they were regarding their business and interacting with the selected customer. Respondents then had to indicate the extent to which they have sufficient knowledge of the customer as well as their level of experience dealing with the customer on five-point Likert-type scales (where 1 = strongly disagree; 5 = strongly agree) were used to measure these items. All but one respondent (99.5\%) had a good amount of knowledge about the customer, with $94.5 \%$ indicating that they also had a good amount of experience with the customer. Consequently, 213 surveys were used as one questionnaire was discarded due to non-response bias.

Table 1 offers an overview of the wide range of industries respondents worked in as well as the broad range of companies in terms of employees and annual turnovers. 
Table 1. Industry, full-time employees and annual turnover

\begin{tabular}{|l|c|c|c|}
\hline \multicolumn{1}{|c|}{ Industry } & Count & Number of full-Time Employees & Count \\
\hline Accommodation, Cafe or Restaurant & 11 & $1-4$ & 9 \\
\hline Agriculture, Forest or Fishing & 9 & $5-9$ & 15 \\
\hline Communication Services & 21 & $10-19$ & 17 \\
\hline Construction & 12 & $20-49$ & 33 \\
\hline Education & 6 & $50-99$ & 35 \\
\hline Electricity, Gas or Water & 13 & $100-249$ & 29 \\
\hline Finance and/or Insurance & 20 & $250+$ & 75 \\
\hline Health \& Community Services & 10 & Annual Turnover (Euro) & \\
\hline Manufacturing & 28 & $0-4.9$ Millions & 52 \\
\hline Personal and Other Services & 10 & $5.0-9.9$ Millions & 16 \\
\hline Property and Business Services & 8 & $10.0-24.9$ Millions & 38 \\
\hline Retail Trade & 19 & $25.0-99.9$ Millions & 37 \\
\hline Transport and Storage & 15 & $1000+$ Millions & 70 \\
\hline Wholesale Trade & 20 & & \\
\hline Other & 11 & & \\
\hline
\end{tabular}

Finally, the study's managerial implications were discussed and verified under three additional sales directors not forming part of the survey. The directors were selected based on a judgmental criterion of having long-standing sales experience to assess the managerial implications adequately.

\subsection{Constructs and items}

Construct items were sourced from the following studies: non-economic satisfaction (Geyskens et al., 1999); economic satisfaction (Sanzo et al., 2003); continuity (Rauyruen \& Miller, 2007); coordination (McNeilly \& Russ, 1992); and cooperation (Payan \& Svensson, 2007). Items were adapted to fit the business-sales representative relationship by changing the term "supplier" to "customer" throughout all items (see Table 2 for item wording). Fivepoint Likert-type scales were used for all items (where $1=$ strongly disagree and $5=$ strongly agree).

\section{Results and analysis}

\subsection{Univariate statistics - construct and item}

Table 2 presents the mean, standard deviation, variance explained and factor loading of each item per construct demonstrating a zero non-response bias. Table 2 furthermore displays the explained variance of construct items (ranging between 0.31 and 0.88 ). In addition, it presents that the factor loadings (ranging between 0.56 and 0.94 ), implying that the items meet the thresholds ( 0.5 for variance explained; 0.7 or larger factor loadings) (Hair et al., 
2006), except for three (namely item "c" of economic satisfaction; "a" of coordination; and item " $c$ " of cooperation). However, Table 2 shows that the thresholds of 0.5 as well as 0.7 were exceeded for explained variance as well as factor loadings respectively.

Table 2. Univariate statistics - construct and items

\begin{tabular}{|c|c|c|c|c|c|}
\hline & $\mathrm{N}$ & Mean & Std Dev & $\begin{array}{l}\text { Variance } \\
\text { Explained }\end{array}$ & $\begin{array}{l}\text { Factor } \\
\text { Loading }\end{array}$ \\
\hline \multicolumn{6}{|l|}{ Economic Satisfaction } \\
\hline a) This customer contributes to our sales goals. & 213 & 4.31 & 0.69 & 0.51 & 0.72 \\
\hline $\begin{array}{l}\text { b) This customer contributes to our financial } \\
\text { performance. }\end{array}$ & 213 & 4.17 & 0.73 & 0.65 & 0.81 \\
\hline $\begin{array}{l}\text { c) This customer generates economic growth } \\
\text { for us. }\end{array}$ & 213 & 4.10 & 0.82 & 0.43 & 0.66 \\
\hline \multicolumn{6}{|l|}{ Non-Economic Satisfaction } \\
\hline $\begin{array}{l}\text { a) The relationship between us and this } \\
\text { customer is positive. }\end{array}$ & 213 & 4.31 & 0.79 & 0.73 & 0.85 \\
\hline $\begin{array}{l}\text { b) Our firm is content about its relationship } \\
\text { with this customer. }\end{array}$ & 213 & 4.34 & 0.73 & 0.73 & 0.85 \\
\hline $\begin{array}{l}\text { c) The relationship between us and this } \\
\text { customer is satisfying. }\end{array}$ & 213 & 4.24 & 0.86 & 0.75 & 0.86 \\
\hline \multicolumn{6}{|l|}{ Continuity } \\
\hline $\begin{array}{l}\text { a) We expect our relationship with this } \\
\text { customer to continue for a long time. }\end{array}$ & 213 & 4.34 & 0.62 & 0.72 & 0.85 \\
\hline $\begin{array}{l}\text { b) Our relationship with this customer is } \\
\text { enduring. }\end{array}$ & 213 & 4.13 & 0.69 & 0.60 & 0.78 \\
\hline $\begin{array}{l}\text { c) Our relationship with this customer is an } \\
\text { alliance that is going to last. }\end{array}$ & 213 & 3.92 & 0.80 & 0.53 & 0.73 \\
\hline \multicolumn{6}{|l|}{ Coordination } \\
\hline a) We work together with this customer. & 213 & 4.02 & 0.87 & 0.44 & 0.69 \\
\hline $\begin{array}{l}\text { b) We work jointly with this customer on issues } \\
\text { that affect both firms. }\end{array}$ & 213 & 3.75 & 0.94 & 0.69 & 0.82 \\
\hline $\begin{array}{l}\text { c) Our processes are coordinated with those of } \\
\text { this customer. }\end{array}$ & 213 & 3.70 & 0.95 & 0.61 & 0.73 \\
\hline \multicolumn{6}{|l|}{ Cooperation } \\
\hline $\begin{array}{l}\text { a) Our relationship with this customer is } \\
\text { cooperative. }\end{array}$ & 213 & 4.12 & 0.89 & 0.71 & 0.85 \\
\hline $\begin{array}{l}\text { b) There is a cooperative attitude between us } \\
\text { and this customer. }\end{array}$ & 213 & 4.09 & 0.72 & 0.88 & 0.94 \\
\hline $\begin{array}{l}\text { c) My firm prefers to cooperate with this } \\
\text { customer. }\end{array}$ & 213 & 4.15 & 0.79 & 0.31 & 0.56 \\
\hline
\end{tabular}




\subsection{Multivariate statistics - measurement and structural research models}

Using SPSS/AMOS 24.0 for the multivariate analyses, confirmatory factor analysis (CFA) was carried out for the constructs included in the research model, followed by structural equation modelling (SEM) to present the structural criteria between the constructs in the research model. The CFA and SEM were both based on measurement and structural models of five constructs and fifteen items as presented in Figure 1. The results of the CFA showed the goodness-of-fit estimates of the measurement model were well in line with acceptable guidelines (Hair et al., 2006), namely: Chi-square (statistically significant at $\mathrm{p}=0.00$ ) was 148.40 at 80 degrees of freedom. Estimates of fit statistics were also well in line with the recommended guidelines: normed Chi-square $\left(\mathrm{X}^{2} / \mathrm{df}\right)=1.86$; $\mathrm{NFI}=0.916, \mathrm{IFI}=0.960 ; \mathrm{TLI}=$ 0.946; CFI $=0.959$; RMSEA $=0.064$ (confidence interval 90\%: 0.047-0.079).

Subsequently, considering that the goodness-of-fit estimates generated by the CFA were all well in line with recommended guidelines, structural equation modelling of the structural model and its hypothesized relationships was performed (see Figure 2).

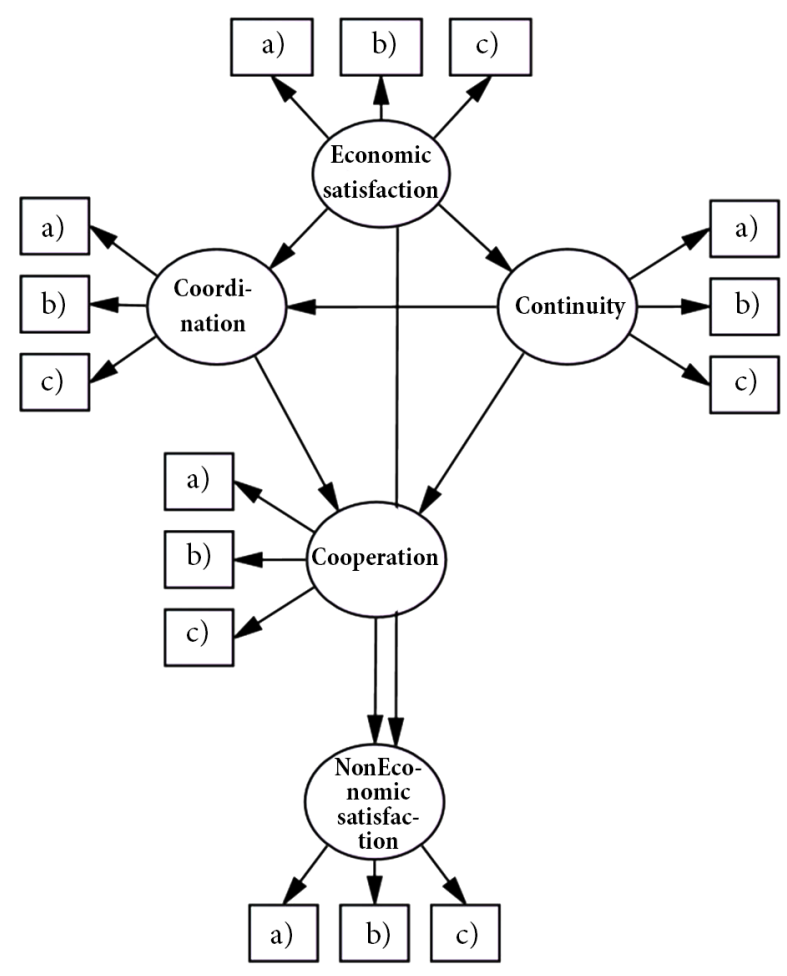

Figure 2. Research model

The results of SEM showed that the goodness-of-fit estimates of the structural model met the recommended indices (Hair et al., 2006): Chi-square $=148.91(\mathrm{df}=83)$.

The estimates of fit statistics also met recommended guidelines: Chi-square statistically significant $(\mathrm{p}=0.00) ; \mathrm{X}^{2} / \mathrm{df}=1.79 ; \mathrm{NFI}=0.916 ; \mathrm{IFI}=0.961 ; \mathrm{TLI}=0.950 ; \mathrm{CFI}=0.961 ; \mathrm{RM}-$ SEA $=0.061$ (confidence interval 90\%: 0.045-0.077). 
Subsequently, the goodness-of-fit estimates generated by the structural equation modelling were all well in line with recommended guidelines. The hypothesized relationships were significant at $\mathrm{p}=0.000-009$ with standardized regression weights between 0.19 and 0.60 (see Table 3).

Table 3. Hypotheses results

\begin{tabular}{|c|l|l|c|c|l|}
\hline Hypothesis & \multicolumn{1}{|c|}{$\begin{array}{c}\text { Exogenous } \\
\text { Construct }\end{array}$} & \multicolumn{1}{|c|}{$\begin{array}{c}\text { Endogenous } \\
\text { Construct }\end{array}$} & $\begin{array}{c}\text { Regression } \\
\text { Weight }\end{array}$ & Significance & Finding \\
\hline 1 & $\begin{array}{l}\text { Economic } \\
\text { Satisfaction }\end{array}$ & Continuity & 0.54 & 0.000 & Supported \\
\hline 2 & $\begin{array}{l}\text { Economic } \\
\text { Satisfaction }\end{array}$ & Coordination & 0.25 & 0.009 & Supported \\
\hline 3 & Continuity & Coordination & 0.35 & 0.000 & Supported \\
\hline 4 & Continuity & Cooperation & 0.36 & 0.000 & Supported \\
\hline 5 & Coordination & Cooperation & 0.38 & 0.000 & Supported \\
\hline 6 & Cooperation & $\begin{array}{l}\text { Non-Economic } \\
\text { Satisfaction }\end{array}$ & 0.60 & 0.000 & Supported \\
\hline 7 & $\begin{array}{l}\text { Economic } \\
\text { Satisfaction }\end{array}$ & $\begin{array}{l}\text { Non-Economic } \\
\text { Satisfaction }\end{array}$ & 0.19 & 0.005 & Supported \\
\hline
\end{tabular}

\subsection{Reliability and validity}

Different estimates were applied to evaluate validity and reliability of constructs included in the research model as presented in Table 4.

Table 4. Squared inter-construct correlations and summary statistics

\begin{tabular}{|l|c|c|c|c|c|}
\hline \multicolumn{1}{|c|}{ Variable } & $(1)$ & $(2)$ & $(3)$ & (4) & (5) \\
\hline (1) Economic Satisfaction & 1,000 & & & & \\
\hline (2) Non-Economic Satisfaction & 0.17 & 1,000 & & & \\
\hline (3) Continuity & 0.29 & 0.17 & 1.000 & & \\
\hline (4) Coordination & 0.19 & 0.20 & 0.24 & 1.000 & \\
\hline (5) Cooperation & 0.14 & 0.45 & 0.30 & 0.30 & 1,000 \\
\hline Variance Extracted & $63.0 \%$ & $73.7 \%$ & $62.0 \%$ & $57.7 \%$ & $63.3 \%$ \\
\hline Composite Trait Reliability & 0.86 & 0.91 & 0.86 & 0.86 & 0.89 \\
\hline
\end{tabular}

Table 4 shows that the variance extracted per constructs was above 50\%, ranging from $57.7 \%$ to $73.7 \%$, thereby meeting convergent validity requirements (Hair et al., 2006).

Also, it can be seen from the Table 4 that the variance extracted per construct is larger than the corresponding squared inter-construct correlations for all constructs, thereby confirming discriminant validity.

Nomological validity (indication of the direction of the hypothesized relationships) was established with all results being in line with those presented in previous research. 
Finally, it can also be seen that the reliability estimates were acceptable (ranging from 0.86 to 0.91 ) by being larger than 0.7 per construct (Hair et al., 2006). The measure is thus deemed valid and reliable under this study population.

\subsection{Rival model}

Table 5 presents a comparison of goodness-of-fit estimates between the research model of this study (see Figure 1) and a rival model.

Table 5. Rival model - comparison of goodness-of-fit measures

\begin{tabular}{|l|c|c|c|c|c|c|c|c|c|c|}
\hline & \multicolumn{3}{|c|}{$\begin{array}{c}\text { Parsimony-Adjusted Fit } \\
\text { Measures }\end{array}$} & \multicolumn{4}{c|}{$\begin{array}{c}\text { Baseline Comparisons - } \\
\text { Incremental Fit Measures }\end{array}$} & $\begin{array}{c}\text { Badness } \\
\text { of fit }\end{array}$ & \multicolumn{2}{c|}{$\begin{array}{c}\text { Relation- } \\
\text { ships }\end{array}$} \\
\hline Index & PRATIO & PNFI & PCFI & NFI & IFI & TLI & CFI & RMSEA & H & Sig \\
\hline Research Model & 0.790 & 0.724 & 0.759 & 0.916 & 0.961 & 0.950 & 0.961 & 0.061 & 7 & 7 \\
\hline Rival Model & 0.762 & 0.698 & 0.731 & 0.916 & 0.960 & 0.946 & 0.959 & 0.064 & 10 & 7 \\
\hline
\end{tabular}

The rival model contained three additional hypothesized relationships as follows: (i) a relationship between economic satisfaction and cooperation, which was non-significant ( $\mathrm{p}$-value equals 0.756 with a regression coefficient of 0.026); (ii) another relationship between continuity and non-economic satisfaction, which was also non-significant (p-value: 0.535; regression coefficient: 0.053); and (iii) a relationship between coordination and non-economic satisfaction (non-significant with $\mathrm{p}=0.770$; regression coefficient: -0.027 ). In conclusion, all three amended hypotheses in the rival model were not supported.

In addition, Table 5 presents that the estimates of Parsimony-Adjusted Fit reveal that the fit of the rival model is less in comparison to this study's research model. The rival model indicates that the constructs of continuity, coordination and cooperation in combination mediates the relationship between the constructs of economic satisfaction and non-economic satisfaction. The relationship between economic and non-economic satisfactions is significant ( $p=0.000$; regression coefficient: 0.478 ), but the mediating effect of continuity, coordination and cooperation reduces the regression coefficient to 0.192 with still a significant $\mathrm{p}$-value of 0.005 . Continuity mediates on its own by reducing the regression coefficient between economic satisfaction and non-economic satisfaction to 0.24 . Coordination also reduces the regression coefficient to 0.24 , as well as cooperation reduces it to 0.26 .

\section{Discussion and managerial implications}

Sales representatives play a significant role in ensuring customer satisfaction (Grewal \& Sharma, 1991), thereby resulting in greater trust, and ultimately long-lasting relationships with customers (Ferro et al., 2016; Friend et al., 2018; Lussier \& Hall, 2018). However, ensuring satisfaction is not sufficient to foster relationships as sales representatives' cooperative intentions and cooperation with customers are essential to establish quality relationships (Huntley, 2006) that would lead to relationship continuance (Holm et al., 1996). 
Although previous studies considered how satisfaction (multidimensional) fits into a nomological network with continuity, coordination and cooperation, these studies were performed within a buyer setting (Padín et al., 2017; Payan et al., 2019) and not within a business sales context. Noting this gap, the aim of the study was to establish a foundation to assess the structural properties between economic satisfaction and non-economic satisfaction in a business sales context.

The research model, which was valid and reliable under Norwegian business-sales representative relationships, established a structure of cause-and-effect between multiple constructs included in this study.

The research and rival models reveal that economic satisfaction relates to continuity and coordination, but it does not relate to cooperation. It also reveals that cooperation relates to non-economic satisfaction, while continuity and coordination do not relate to economic satisfaction. These findings are in line with Payan et al. (2019) who found that coordination relates to economic satisfaction due to its alignment of actions, while cooperation relates to non-economic satisfaction due to its alignment of interest.

Many existing relationship constructs need further attention to verify their relationships to either economic satisfaction or non-economic satisfaction, or both. Previous studies on business relationships define and measure to a large extent satisfaction as non-economic (Payan et al., 2019), while the economic constituent of satisfaction often is omitted. It means that existing theory suffers from a shortage in understanding the economic incentives to act and interact in one way or the other. Subsequently, the economic constituent remains to some extent unexplored.

From the findings from this study a number of managerial implications could be derived that were discussed, and the practical relevance and implementation thereof validated (under sales directors who didn't participate in the study). The practitioners furthermore provided input as to how the findings from the study could hold practical implications within a sales environment.

A first important managerial implication is that satisfied sales representatives will also generate positive consequences for the customer, not only for the salesperson and selling company, as they contribute to coordination, cooperation and continuity in the relationship. Thus, the sales representative and buyer stands to benefit. The implications resulting from ensuring economic and non-economic satisfaction in business-sales representative relationships include that sales representatives will prioritize customers generating economic satisfaction and will be more willing to not only share information with profitable customers, but also engage in trustful communication with them as they will be more comfortable and happy with these customers.

Concerning continuity, the practitioners agreed that when sales representatives expect continuity in the relationship, they will focus on existing customers and spend less time hunting for new customers. Expectations of continuity will also result in sales representatives focusing on profitable customers and on investing in developing and maintaining relationship.

Coordinating activities with customers may lead to favorable actions in business-sales representative relationships, thereby creating the foundation to create a win-win situation for sales representatives and customers. Further implications stemming from coordination in- 
clude that sales representatives and customers join forces to enhance efforts towards end user solutions; it becomes easier to implement shared software solutions to advance interaction in the business-sales representative relationship; working with customers is more efficient; and it becomes easier to adjust to changes in the market.

The practitioners concurred with the managerial implications resulting from cooperation, including that it will result in a greater avoidance of problems, thereby contributing to openness in the relationship. Cooperation furthermore facilitates understanding customer demands and the manner in which they can be met; solutions to problems become easier; and sales representatives will be more inclined to begin collaborative projects, such as new product development, with customers. Finally, sales representatives' willingness to invest time and resources in the relationship will increase, thereby holding potential for greater profitability.

The sales directors furthermore indicated that our findings showing that continuity, coordination and cooperation are mediators between economic and non-economic satisfaction in business-sales representative relationships makes sense within a sales environment. A final managerial implication, as supported by the practitioners, is accordingly that it may be better for customers not to always demand the lowest prices, largest discounts and the most expensive logistic solutions because a satisfied sales representatives will work more efficiently with the customer, initiate and support joint projects, meet customer needs, actively invest in solving problems and reduce the costs associated with changing suppliers.

\section{Conclusions}

Although there are several studies that focus on the relationship between non-economic and economic satisfaction, it is not until recently that studies on business relationships explicitly focus on mediators between these constructs, thus not as antecedents and postcedents of satisfaction. However, existing theory needs further research on the economic incentives in relation to existing insights and knowledge in literature.

This study offers a number of contributions. In contrast to most studies conducted within a buyer setting, this study offers insights into a business sales context. Secondly, it addressed the gap in literature on how multidimensional satisfaction fits into a nomological network with continuity, coordination and cooperation.

This study also contributes by revealing that the constructs of continuity, coordination and cooperation to some extent mediates separately as well as cumulatively the relationship between non-economic satisfaction and economic satisfaction in business-sales representative relationships. Subsequently, it contributes to an extended understanding concerning existing theory and earlier research within business relationships relating to a sales perspective. A noteworthy contribution for practitioners based on the study findings, and as supported by the sales directors interviewed in the study, is that sales representatives will invest in building stronger relationships with existing customers if they expect the relationship to continue, thereby increasing the organization's profitability. Nevertheless, the results suffer from limitations that offer opportunities for further research. 
This study is limited to Norwegian business-sales representative relationships. An opportunity therefore exists to research business-sales representative relationships in other countries, as well as to test the research model within a business buyer relationship context. Another opportunity is to research other constructs as mediators or moderators between non-economic and economic satisfaction specifically within business-sales representative relationships, such as commitment and trust.

\section{Author contributions}

The authors are jointly responsible for this research paper.

\section{Disclosure statement}

The authors declare no conflict of interest.

\section{References}

Anderson, J. C., \& Narus, J. A. (1990). A model of distributor firm and manufacturer firm working partnerships. Journal of Marketing, 48(4), 62-74. https://doi.org/10.1177/002224298404800407

Bradford, K. D., Liu, Y., Shi, Y., Weitz, B. A., \& Xu, J. (2019). Harnessing internal support to enhance customer relationships: The role of networking, helping, and allocentrism. Journal of Marketing Theory and Practice, 27(2), 140-158. https://doi.org/10.1080/10696679.2019.1577687

Campbell, D. T. (1955). The informant in quantitative research. American Journal of Sociology, 60(3), 339-342. https://doi.org/10.1086/221565

Chu, S., Cao, Y., Yang, J., \& Mundel, J. (2019) Understanding advertising client-agency relationships in China: A multimethod approach to investigate Guanxi dimensions and agency performance. Journal of Advertising, 48(5), 473-494. https://doi.org/10.1080/00913367.2019.1663318

Dabholkar, P. A., Johnston, W. J., \& Cathey, A. S. (1994). The dynamics of long-term business-tobusiness exchange relationships. Journal of Academy of Marketing Science, 22(2), 130-145. https://doi.org/10.1177/0092070394222003

Del Bosque Rodriguez, I., Collado Agudo, J., \& San Martín Gutiérrez, H. (2006). Determinants of economic and social satisfaction in manufacturer-distributor relationships. Industrial Marketing Management, 35, 666-675. https://doi.org/10.1016/j.indmarman.2005.05.006

Farrelly, F. J., \& Quester, P. J. (2005). Examining important relationship quality constructs of the focal sponsorship exchange. Industrial Marketing Management, 34(3), 211-219.

https://doi.org/10.1016/j.indmarman.2004.09.003

Fehr, L. C. F., \& Rocha, W. (2018). Open-book accounting and trust: Influence on buyer-supplier relationship. RAUSP Management Journal, 53(4), 597-621. https://doi.org/10.1108/RAUSP-06-2018-0034

Ferro, C., Padín, C., Svensson, G., \& Payan, J. (2016). Trust and commitment as mediators between economic and non-economic satisfaction in manufacturer-supplier relationships. Journal of Business \& Industrial Marketing, 31(1), 13-23. https://doi.org/10.1108/JBIM-07-2013-0154

Friend, S. B., Johnson, J. S., \& Sohi, R. S. (2018). Propensity to trust salespeople: A contingent multilevel-multisource examination. Journal of Business Research, 83, 1-9.

https://doi.org/10.1016/j.jbusres.2017.09.048 
Garbarino, E., \& Johnson, M. S. (1999). The different roles of satisfaction, trust, and commitment in customer relationships. The Journal of Marketing, 63(2), 70-87.

https://doi.org/10.1177/002224299906300205

Geyskens, I., \& Steenkamp, J. E. M. (2000). Economic and social satisfaction: Measurement and relevance to marketing channel relationships. Journal of Retailing, 76(1), 11-32.

https://doi.org/10.1016/S0022-4359(99)00021-4

Geyskens, I., Steenkamp, J. E. M., \& Kumar, N. (1999). A meta-analysis of satisfaction in marketing channel relationships. Journal of Marketing Research, 36(2), 223-239. https://doi.org/10.1177/002224379903600207

Glas, A. H., Lipka, P., \& Essig, M. (2019). Misperceptions in interfunctional supply management: Workshare coordination vs. integrated cooperation. Supply Chain Forum: An International Journal, 20(2), 89-103. https://doi.org/10.1080/16258312.2019.1586268

Glavee-Geo, R. (2019). Does supplier development lead to supplier satisfaction and relationship continuation? Journal of Purchasing and Supply Management, 25, 100537. https://doi.org/10.1016/j.pursup.2019.05.002

Goncalves, H. M., \& Sampaio, P. (2012). The customer satisfaction-customer loyalty relationship. Management Decision, 50(9), 1509-1526. https://doi.org/10.1108/00251741211266660

Grewal, D., \& Sharma, A. (1991). The effect of salesforce behavior on customer satisfaction: An interactive framework. The Journal of Personal Selling and Sales Management, 11(3), 13-23.

Hagen, J. M., \& Choe, S. (1998). Trust in Japanese interfirm relations: Institutional sanctions matter. Academy of Management Review, 23(3), 589-600. https://doi.org/10.5465/amr.1998.926628

Hair, J. F., Black, W. C., Babin, B. J., Anderson, R. E., \& Tatham, R. L. (2006). Multivariate data analysis ( $6^{\text {th }}$ ed.). Prentice Hall.

Harmon, T. R., \& Griffiths, M. A. (2008). Franchisee perceived relationship value. Journal of Business \& Industrial Marketing, 23(4), 256-263. https://doi.org/10.1108/08858620810865834

Høgevold, N., Svensson, G., \& Otero-Neira, C. (2019). Validating action and social alignment constituents of collaboration in business relationships: A sales perspective. Marketing Intelligence \& Planning, 37(7), 721-740. https://doi.org/10.1108/MIP-12-2018-0577

Holm, D. B., Eriksson, K., \& Johanson, J. (1996). Global perspectives on cooperative strategies. Journal of International Business Studies, 27(5), 1033-1053. https://doi.org/10.1057/palgrave.jibs.8490162

Huntley, J. K. (2006). Conceptualization and measurement of relationship quality: Linking relationship quality to actual sales and recommendation intention. Industrial Marketing Management, 35(6), 703-714. https://doi.org/10.1016/j.indmarman.2005.05.011

Hyun, S. S. (2010). Predictors of relationship quality and loyalty in the chain restaurant industry. Cornell Hospitality Quarterly, 51(2), 251-267. https://doi.org/10.1177/1938965510363264

Jap, S. D. (2001). The strategic role of the salesforce in developing customer satisfaction across the relationship lifecycle. Journal of Personal Selling \& Sales Management, 21(2), 95-108.

Jiang, Z., Shiu, E., Henneberg, S., \& Naude, P. (2016). Relationship quality in business to business relationships - Reviewing the current literatures and proposing a new measurement model. Psychology \& Marketing, 33(4), 297-313. https://doi.org/10.1002/mar.20876

Jones, M. A., \& Suh, J. (2000). Transaction-specific satisfaction and overall satisfaction: An empirical analysis. Journal of Services Marketing, 14(2), 147-159. https://doi.org/10.1108/08876040010371555

Ju, C. B., \& Ha, Y. (2019). An empirical analysis of the stage model of business-to-business relationships in South Korea: A longitudinal study. Asia Pacific Business Review, 25(3), 367-391. https://doi.org/10.1080/13602381.2018.1551987

Kang, J., Asare, A. K., Brashear-Alejandro, T., Granot, E., \& Li, P. (2018). Interorganizational drivers of channel performance: A meta-analytic structural model. Journal of Business \& Industrial Marketing, 33(2), 193-195. https://doi.org/10.1108/JBIM-09-2016-0218 
Kumar, N., Scheer, L. K., \& Steenkamp, J. E. M. (1995). The effects of perceived interdependence on dealer attitudes. Journal of Marketing Research, 32(3), 348-356. https://doi.org/10.1177/002224379503200309

Latdict. (2018). Latin dictionary \& grammar resources. http://latin-dictionary.net/definition/14137/ cooperor-cooperari-cooperatus

Lee, D., Jeong, I., Lee, H., \& Sung, J. (2008). Developing a model of reciprocity in the importer-exporter relationship: The relative efficacy of economic versus social factors. Industrial Marketing Management, 37(1), 9-22. https://doi.org/10.1016/j.indmarman.2007.06.009

Lussier, B., \& Hall, Z. R. (2018). Cooperation in B2B relationships: Factors that influence customers' perceptions of salesperson cooperation. Industrial Marketing Management, 69, 209-220. https://doi.org/10.1016/j.indmarman.2017.09.019

Malone, T. W. (1988). What is Coordination Theory? Massachusetts Institute of Technology, Cambridge, Mass.

Malone, T. W., \& Crowston, K. (1994). The interdisciplinary study of coordination. ACM Computing Surveys (CSUR), 26(1), 87-119. https://doi.org/10.1145/174666.174668

Mangus, S. M., \& Ruvio, A. (2019). Do opposites attract? Assimilation and differentiation as relationship-building strategies. Journal of Personal Selling \& Sales Management, 39(1), 60-80. https://doi.org/10.1080/08853134.2018.1471696

Mbango, P., \& Mmatli, W. (2019). Precursors and outcomes of satisfaction in business-to-business relationship marketing: Insights from Hawkers/street vendors leafy vegetable market in South Africa. Cogent Social Sciences, 5(1), 1573954. https://doi.org/10.1080/23311886.2019.1573954

McNeilly, K. M., \& Russ, F. A. (1992). Coordination in the marketing channel. Advances in Distribution Channel Research, 1(2), 161-186.

Medlin, C. J., Aurifeille, J., \& Quester, P. G. (2005). A collaborative interest model of relational coordination and empirical results. Journal of Business Research, 58(2), 214-222. https://doi.org/10.1016/S0148-2963(02)00496-4

Morgan, R. M., \& Hunt, S. D. (1994). The commitment-trust theory of relationship marketing. The Journal of Marketing, 58(3), 20-38. https://doi.org/10.1177/002224299405800302

Mpinganjira, M., Bogaards, M., Svensson, G., Mysen, T., \& Padín, C. (2013). Satisfaction in relation to the metrics of quality constructs in South African manufacturer-supplier relationships. Esic Market Economic and Business Journal, 44(1), 55-71. https://doi.org/10.7200/esicm.144.0441.2i

Mpinganjira, M., Roberts-Lombard, M., \& Svensson, G. (2017). Validating the relationship between trust, commitment, economic and non-economic satisfaction in South African buyer-supplier relationships. Journal of Business \& Industrial Marketing, 32(3), 421-431. https://doi.org/10.1108/JBIM-04-2015-0073

Mungra, Y., \& Yadav, P. K. (2020). The mediating effect of satisfaction on trust-commitment and relational outcomes in manufacturer-supplier relationship. Journal of Business and Industrial Marketing, 35(2), 219-230. https://doi.org/10.1108/JBIM-09-2018-0268

Naudé, P., \& Buttle, F. (2000). Assessing relationship quality. Industrial Marketing Management, 29(4), 351-361. https://doi.org/10.1016/S0019-8501(00)00112-7

Noordewier, T. G., John, G., \& Nevin, J. R. (1990). Performance outcomes of purchasing arrangements in industrial buyer-vendor relationships. The Journal of Marketing, 54(4), 80-93. https://doi.org/10.1177/002224299005400407

Nyaga, G. N., Whipple, J. M., \& Lynch, D. F. (2010). Examining supply chain relationships: Do buyer and supplier perspectives on collaborative relationships differ? Journal of Operations Management, 28(2), 101-114. https://doi.org/10.1016/j.jom.2009.07.005 
Oliver, R. L., Rust, R. T., \& Varki, S. (1997). Customer delight: Foundations, findings, and managerial insight. Journal of Retailing, 73(3), 311-336. https://doi.org/10.1016/S0022-4359(97)90021-X

Padín, C., Ferro, C., \& Svensson, G. (2017). Validity and reliability of satisfaction as a mediator between quality constructs in manufacturer-supplier relationships through time and across contexts. Journal of Business-to-Business Marketing, 24(1), 1-17. https://doi.org/10.1080/1051712X.2016.1275799

Palmatier, R. W. (2008). Relationship marketing. Marketing Science Institute, Cambridge, Mass.

Palmatier, R. W., Dant, R. P., Grewal, D., \& Evans, K. R. (2006). Factors influencing the effectiveness of relationship marketing: A meta-analysis. Journal of Marketing, 70(4), 136-153. https://doi.org/10.1509/jmkg.70.4.136

Payan, J. M., \& Svensson, G. (2007). Co-operation, coordination, and specific assets in inter-organisational relationships. Journal of Marketing Management, 23(7-8), 797-813. https://doi.org/10.1362/026725707X230045

Payan, J. M., Padín, C., Ferro, C., \& Svensson, G. (2019). Action and social alignment components of collaboration in SME business relationships. Journal of Small Business \& Entrepreneurship, 31(6), 463-481. https://doi.org/10.1080/08276331.2018.1459014

Payan, J. M., Svensson, G., Awuah, G., Andersson, S., \& Hair, J. (2010). A cross-cultural RELQUALscale in supplier-distributor relationships of Sweden and the USA. International Marketing Review, 27(5), 541-561. https://doi.org/10.1108/02651331011076581

Pei, Z., Yan, R., \& Ghose, S. (2020). Which one is more valuable in coordinating the online and offline distribution? Service support or online price coordination. Industrial Marketing Management, 87, 150-159. https://doi.org/10.1016/j.indmarman.2020.02.007

Poppo, L., \& Zenger, T. (2002). Do formal contracts and relational governance function as substitutes or complements? Strategic Management Journal, 23(8), 707-725. https://doi.org/10.1002/smj.249

Rauyruen, P., \& Miller, K. E. (2007). Relationship quality as a predictor of B2B customer loyalty. Journal of Business Research, 60(1), 31-31. https://doi.org/10.1016/j.jbusres.2005.11.006

Rodriguez, R., Svensson, G., \& Román, R. (2018). Comparing the life-cycles of service sales between buyers and sellers in business relationships through a teleological lens. International Journal of Business Excellence, 15(1), 95-113. https://doi.org/10.1504/IJBEX.2018.091282

Rutherford, B. (2012). Building buyer commitment to the salesperson. Journal of Business Research, 65(7), 960-967. https://doi.org/10.1016/j.jbusres.2011.05.001

Sahadev, S. (2008). Economic satisfaction and relationship commitment in channels: The moderating role of environmental uncertainty, collaborative communication and coordination strategy. European Journal of Marketing, 42(1/2), 178-195. https://doi.org/10.1108/03090560810840961

Sanzo, M. J., Santos, L., Vásquez, R., \& Álvarez, L. I. (2003). The effect of market orientation on buyerseller relationship satisfaction. Industrial Marketing Management, 32(4), 327-345. https://doi.org/10.1016/S0019-8501(01)00200-0

Sarmah, S. P., Acharya, D., \& Goyal, S. K. (2006). Buyer vendor coordination models in supply chain management. European Journal of Operational Research, 175(1), 1-15. https://doi.org/10.1016/j.ejor.2005.08.006

Sosa-Varela, J. C., Svensson, G., \& Mysen, T. (2011). A construct of META-RELQUAL in Puerto Rican business relationships. ESIC Market, 140, 27-55.

Svensson, G., \& Mysen, T. (2011). A construct of META-RELQUAL: Measurement model and theory testing. Baltic Journal of Management, 6(2), 227-244. https://doi.org/10.1108/17465261111131820

Svensson, G., Mysen, T., \& Payan, J. (2010). Balancing the sequential logic of quality constructs in manufacturing-supplier relationships - Causes and outcomes. Journal of Business Research, 63(11), 1209-1214. https://doi.org/10.1016/j.jbusres.2009.10.019 
Svensson, G., Mysen, T., Rindell, A., \& Billström, A. (2013). Validation of a META-RELQUAL construct through a Nordic comparative study. Marketing Intelligence \& Planning, 31(1), $72-87$. https://doi.org/10.1108/02634501311292939

Ting, S. (2011). The role of justice in determining relationship quality. Journal of Relationship Marketing, 10(2), 57-75. https://doi.org/10.1080/15332667.2011.577732

Ulaga, W., \& Eggert, A. (2006). Relationship value and relationship quality. Broadening the nomological network of business-to-business relationships. European Journal of Marketing, 40(3/4), 311-327. https://doi.org/10.1108/03090560610648075

Wilson, E. J., \& Nielson, C. C. (2001). Cooperation and continuity in strategic business relationships. Journal of Business-to-Business Marketing, 8(1), 1-24. https://doi.org/10.1300/J033v08n01_01

Woo, K., \& Ennew, C. T. (2004). Business-to-business relationship quality: An IMP interaction-based conceptualization and measurement. European Journal of Marketing, 38(9/10), 1252-1271. https://doi.org/10.1108/03090560410548960 